\title{
DEFENSE FINANCING FEATURES WITHIN THE CONTEXT OF THE NEW CHALLENGES
}

\section{OKSANA CHEBERYAKO}

\author{
Doctor of Historical Science, Ph. D. in Economics, Professor, \\ Taras Shevchenko National University of Kyiv, Ukraine, \\ cheberyako@ukr.net
}

\section{VIKTOR KOLESNYK}

\section{Doctor of Historical Science, Professor,}

Taras Shevchenko National University of Kyiv, Ukraine, kolesnykvf@ukr.net

\section{ALINA GAIDUCHENKO Senior Teacher, National Academy of Security Service of Ukraine, gaiduchenko.alina@gmail.com}

Abstract. The beginning of the third millennium was marked by the desire of the leader countries (USA, China, and Russia) to geopolitical, geostrategic and geo-economic redistribution of spheres of influence. The collapse of the USSR, the dissolution of the Warsaw Pact Organization, the end of the Cold War did not bring the world closer to stability and security. Military force capabilities continue to be considered as one of the most powerful factors in world politics. Proof of this is the intensification of the struggle of the worldss superpowers for regional and global leadership, control over oil, gas and energy flows. It is worth mentioning the Transnistrian conflict, Russia-Led wars in South Ossetia and Abkhazia, the Russian-Georgian war in August 2008, the civil war in Syria, the intensification of Islamic extremism within the ISIS, Russiass annexation of Crimea, the hybrid war unleashed and continues to wage by the Russian Federation against Ukraine. In this connection, it is becoming increasingly important to provide corresponding levels for the defense budget funding. Thus, the study of the peculiarities of defense financing in Ukraine and powerful military superpowers is of considerable scientific, practical and political interest. Comparing the defense expenditures of different countries makes it possible to identify key problem issues in the defense financing of Ukraine and bring the corresponding costs to international standards. This indicator is one of the most important criteria that characterize the statess desire for development, relevant combat readiness of the armed forces and other military forces in the face of new challenges.

The last years of the previous century were characterized by global geopolitical changes and growing contradictions, which resulted in: the transformation of the bipolar model (USA - USSR) into a multipolar (powerful military superpowers - the USA, Russia, China, Saudi Arabia, France, Japan, Germany, India, Brazil)); globalization of world economic processes; erosion through «hybrid wars», which are a new kind of global confrontation in todayss destabilized international security environment, the facets of the division between war and peace.

The availability of weapons of mass destruction and high-precision weapons in the third millennium, the growth of their capacity, the complexity of military equipment and combat assets, the use of new methods and means of warfare have led to significant changes in the functions and tasks of the armed forces, increasing their number and government spending on defense purposes. Today there are about 200 armies in the world with a total number of $24-25$ million people (about $0.4 \%$ of the worldıs population) (Military..., 2002). The state of the troops of any state must correspond to its economic capabilities and at the same time ensure the implementation of national security tasks.

KEYWORDS: DEFENSE FINANCING, DEFENSE BUDGET, HYBRID WARS, MILITARY DOCTRINE, MILITARY SECURITY, NATIONAL SECURITY, NATO, WARSAW PACT.

For citation: Cheberyako, O., Kolesnyk, V., \& Gaiduchenko, A. (2020). Defense Financing Features Within the Context of The New Challenges. Globalization and Business, 10. 163-169. https://doi.org/10.35945/gb.2020.10.020 
The latest fourth-generation wars, a complicated and unstable form of relations in the international arena, are "hybrid wars", which are replacing classical wars in the form of chains of armed conflicts, which have a hidden nature and are usually erupted in political, economic, informational and other spheres. In this case, the armed forces are often involved in small numbers to carry out certain tasks (Cheberyako, Varnalii, 2017).

From time immemorial, the armed forces have been the main and principal guarantor of any country independence and the security of its citizens. Diplomacy and interstate treaties are also important factors in international stability, but as experience shows, when it comes to military conflict, they often do not work, and events in Ukraine and Georgia are clear evidence of this.

Ukrainess national security conditions have deteriorated significantly since 2013 due to interstate and transnational conflicts over natural resources, environmental problems, and facilities that cross state borders and emerge the sovereignty of individual states. All this is aggravated by the global financial and economic recessions and a number of other factors as well.

The military aggression of the Russian Federation, the issue of protection of state independence, and the territorial integrity of Ukraine were transferred to the practical plane. Russiass occupation of part of the territory of Ukraine is accompanied by the destruction of the system of world and national security, the principles of international law. It is obvious that under these conditions, it is urgent and justified to increase, in accordance with the new Military Doctrine, the amount of funding for the defense of Ukraine, as well as other states that support it as full-fledged subjects of international relations.

In general, the financing of the defense of a country depends on the military doctrine adopted by it. There are three main approaches to its formation:

- total waiver of military expenditures (Andorra, Costa Rica, Grenada, Liechtenstein, the Marshall Islands, one of the smallest countries in the world - Nauru, the island nation of Palau, Samoa, the Solomon Islands);

- creation of a powerful military superpower (USA, China, Russia, Saudi Arabia, France, Japan, Germany, India, Brazil);
- financing of defense on the principle of minimal sufficiency (Ukraine before the armed aggression of the Russian Federation) (Cheberyako, 2017).

Prior to the hybrid war unleashed by Russia, Ukraine was not a full member of the international security system and relied on its own forces. At the same time, defense spending was financed according to the third approach, which was relatively small and sometimes amounted to less than $1 \%$ of GDP. This level of funding was inadequate, negatively affecting the effectiveness of the Armed Forces of Ukraine, their combat capability and combat readiness. World practice shows that defense spending less than $1 \%$ of GDP annually leads to a complete loss of defense capability. Nowadays, Ukraine is pursuing a course of Euro-Atlantic integration and NATO membership, striving to become an element of the new architecture of European security in the future, where its vital interests will be ensured collectively with the direct participation of Ukraine itself. Without membership in the North Atlantic Alliance, a system of collective security, Ukraine will no longer have effective leverage to influence decisions taking into account its national interests.

The main source of defense funding in Ukraine is the State Budget, and the amount of relevant expenditures is determined by the Law of Ukraine "On the State Budget of Ukraine for the relevant year». In this case, defense expenditures in accordance with the law must be at least $3 \%$ of the planned GDP (Article 2 of the Law of Ukraine «On Defense of Ukraine»). In addition, since 2014, there has been an additional source - charitable donations of individuals and legal entities (Law of Ukraine "On Amendments to Certain Legislative Acts of Ukraine to Strengthen the Material and Financial Support of the Statess Defense Capability»).

The level of national defense expenditures as a percentage of GDP and total state budget expenditures, as is customary, is one of the most important indicators of a statess defense capability (Table 1).

Table 1 demonstrates that the expenditures of the Ministry of Defense of Ukraine during 2011-2019 amounted to less than $3 \%$ of GDP, although this financial regulation is provided and enshrined in the New Military Doctrine.

In NATO countries, defense spending usually constitutes 2.2-2.5\% of GDP. Reduction of this indicator of financing, as practice shows, does not provide the necessary level of the

Table 1.

Expenditures on defense from the state budget of Ukraine in 2011-2018

\begin{tabular}{|c|c|c|c|c|c|c|c|c|c|c|}
\hline Indicator & 2011 & 2012 & 2013 & 2014 & 2015 & 2016 & 2017 & 2018 & 2019 & $\begin{array}{c}2020 \\
(\mathrm{plan})\end{array}$ \\
\hline $\begin{array}{c}\text { Defense expenditure as a } \\
\text { percentage of GDP, \% }\end{array}$ & 1,04 & 1,16 & 1,05 & 0,97 & 2,32 & 2,5 & 2,5 & 2,7 & 2,68 & 2,6 \\
\hline $\begin{array}{c}\text { Defense expenditure in the } \\
\text { structure of DB expenditure, \% }\end{array}$ & 3,9 & 3,6 & 3,7 & 6,36 & 9,01 & 8,67 & 8,86 & 9,84 & 9,94 & 9,96 \\
\hline Current prices, million UAH & 13241,1 & 14485,7 & 14843,0 & 27363,4 & 52005,2 & 59348,9 & 74346,2 & 97024,0 & 106627,7 & 117510,0 \\
\hline
\end{tabular}

Source: compiled by authors on the basis of Ukrainian Ministry of Finance (MoF) data. 
state protection. The optimal expenditure structure of the classic military budget of NATO countries, as a rule, consists of three parts:

- personnel costs (up to 50\%);

- operating expenses (20\%);

- financing of defense R\&D (up to $10 \%$ ) and acquisition of new weapons and equipment (up to $20 \%$ ).

The disadvantage of the defense budget of Ukraine before the armed aggression of Russian Federation was that its structure did not meet international standards (Fig. 1).

Thus, in Ukraine up to $80 \%$ of funds were spent on the maintenance of the main staff. These costs can rightly be called "eating the budget», because there were no funds left for such items as "purchase of weapons and military equipment» and "research and development». As a result, in 2014, the Armed Forces of Ukraine were unable to carry out the tasks assigned to them. Expenditures on the development of armaments and military equipment increased in 20142015 , but in general the structure of the military budget is changing very slowly. It is quite obvious that this process will take some time.

Every year, the Global Firepower web resource publishes an estimate of the total military power of each country in the world which is based on 55 indicators: the quantities of weapons, military equipment, the total strength of the arm, transport infrastructure, military budget, access to oil, etc. This does not take into account the combat experience of armies. Ranking among the world's strongest military powers Ukraine possesses 27th position out of 138, and among European countries - 9th place out of 50.

According to the Stockholm Institute for Peace (SIPRI), all countries in the world spent 1917 billion dollars on defense in 2019. This is the largest amount since the global financial crisis of 2008 and is probably the peak of military spending. Overall, defense spending on the planet was $2.2 \%$ of world GDP, or about \$ 249 per person (Rating..., 2020).

Recently, Ukrainess neighboring states - Poland, Slovakia, Hungary, Romania, Moldova, Belarus and Russia are actively arming themselves, technically upgrading their armies, and their defense spending is constantly rising. Amid such an active rearmament, first of all of Russia, Ukrainess defense capabilities need to be constantly increased.

Nowadays, the world's ten strongest armies are the United States, China, Russia, India, France, Japan, South Korea, Britain, Turkey and Germany. The three leaders - the United States, China and Russia - remain unchanged. The expenditures of these states on defense financing since 1914 are shown in Table 2.

After emerging from the Great Depression and winning World War II, the United States became the world's most

Fig. 1. Structure of MDU expenditures in 2010 - 2015 years, in \%.

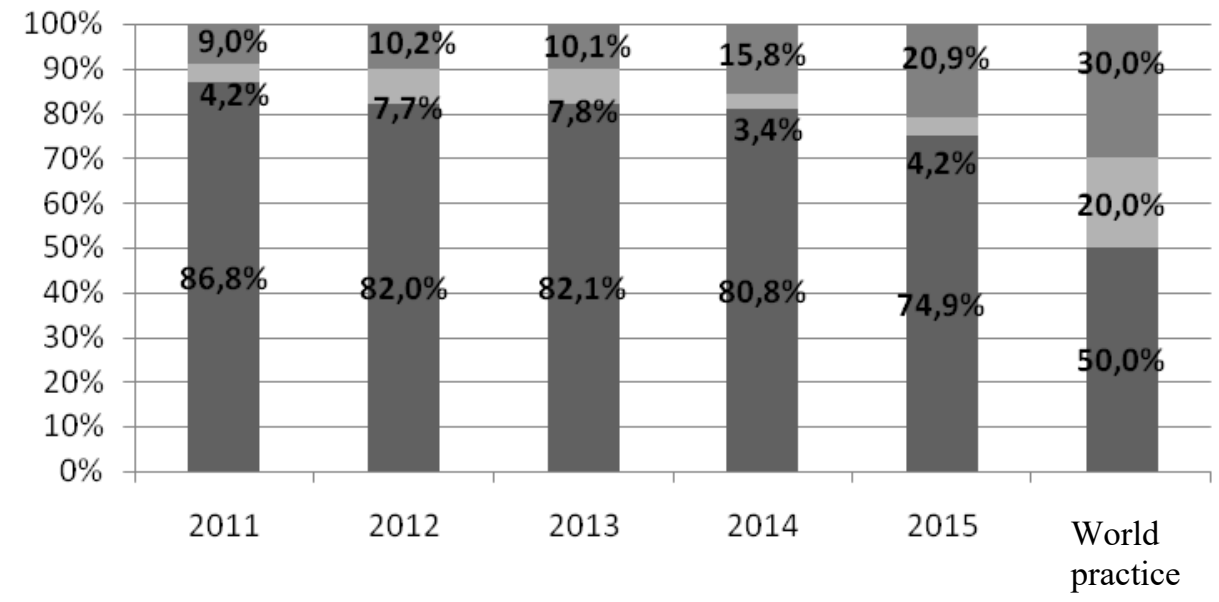

Development of armaments and military equipment

- Training of the Armed Forces of Ukraine

- Maintenance of the Armed Forces of Ukraine

Source: Own calculations according to the Laws of Ukraine "On the State Budget for the relevant year».

Table 2.

Military expenditures of military superpowers in 2014 - 2020, (billion dollars)

\begin{tabular}{|c|c|c|c|c|c|c|c|}
\hline Country & 2014 & 2015 & 2016 & 2017 & 2018 & 2019 & 2020 \\
\hline USA & 753,6 & 736,4 & 767,6 & 818,9 & 890,8 & 904,3 & 935,8 \\
\hline China & 200,0 & 213,5 & 225,6 & 238,5 & $253, .4$ & 261,0 & - \\
\hline Russia & 68,4 & 73,7 & 79,0 & 63,6 & 61,4 & 65,1 & - \\
\hline
\end{tabular}

Source: calculated and compiled by authors on the basis of Stockholm International Peace Research Institute data, US Military Budget. 
influential market economy country, outpacing all other countries in military spending. This status of the United States was determined by postwar documents. The main documents displayed the results of the Bretton Woods Conference, which secured for the United States the status of world economic leader and the 1949 North Atlantic Treaty. This treaty united North American and Western European countries (USA, Canada, Iceland, Great Britain, France, Belgium, the Netherlands, Luxembourg, Norway, Denmark, Italy and Portugal) into a military alliance (the North Atlantic Alliance, or NATO) to counter socialist countries. According to it, the member countries of the union undertook to collectively protect any party to the treaty that will be attacked. Indeed, the North Atlantic Alliance became a system of collective security of the "western» world from the USSR and the subsequent union of the Warsaw Pact countries (The North...,2020).

The United States has become the informal leader of the North Atlantic Alliance as the country with the strongest economy at the time, the least affected by the war. Until the end of the Cold War and the collapse of the Soviet Union together with the socialist bloc, NATO did not officially participate in any military conflict, although it expanded in number. After 1991, the Alliance virtually lost its main goal - protection from the Warsaw Pact countries - and began to participate mainly in the UN peacekeeping missions to settle the internal conflicts of certain countries (Yugoslavia, the Middle East). For the time being, the bloc has 30 countries.

The US military doctrine, in accordance with Chapter 10 of the United States Code, is a set of all the basic rules and principles of the US military to organize and ensure the security of the people and the state through political, diplomatic, economic and military measures (The United..., 2020). The US Congress is the main body of civilian control over the Armed Forces; it approves the military doctrine of the state and plans to reform the armed forces, as well as the US military budget law. The Congress reserves the right to declare war on the state, but this privilege actually remains the prerogative of the presidential power.

The US military spending is the second substantial item in the federal budget after social security (almost $20 \%$ of the total federal budget), which consists of four components:
- first, it is the base budget of the Ministry of Defense (\$ 636 billion for 2020);

- second, foreign emergency operations to combat the Islamic State group (\$ 69 billion for 2020);

- third, these are other agencies that protect the nation (\$228 billion for 2020).

- fourth, other agencies - internal security (\$50 billion), the State Department (\$44 billion), the National Nuclear Safety Administration in the Department of Energy $(\$ 20$ billion), the $\mathrm{FBI}$, and cyber security in the Department of Justice (\$ 9.8 billion) (US Military..., 2020)

In general, the United States Armed Forces includes the Army, Navy, Air Force, Marine Corps, and Coast Guard. All of them are subordinated to the Ministry of Defense, except for the Coast Guard, for which the Ministry of National Security is responsible.

Operationally, the United States Armed Forces is divided into the Joint Forces Command, which is a combination of several branches of Armed Forces intended to perform tasks in a particular region of the globe. There are 10 combat commands: European, Pacific, African and others.

According to the degree of operational readiness, the US Armed Forces is divided into those that carry out their tasks on a regular basis, and the reserve forces (in the Army and Air Force - the National Guard and the Reserve of the relevant type of Armed Forces, in the Navy - only the Navy Reserve and Marines).

According to the Stockholm Institute for Peace Studies (SIPRI), the United States is the absolute leader among countries in terms of military budgets. The US defense spending in 2020 is about 936 billion dollars (Stockholm..., 2020) and this is the largest amount in the history of the country. Enormous financial costs are aimed at making the US Armed Forces more mobile, innovative and «deadly». The dynamics of total US defense spending in recent years (Fig. 2) shows a steady growth of an average of $5 \%$ (National..., 2020)

The US military budget for 2020 includes increased funding to ensure European security and counter potential Russian aggression. So, 734 million dollars are allocated within the framework of the European Defense Initiative and for programs to provide security assistance to Ukraine. Thus, the cost for increasing Ukrainess defense capacity, including

Fig. 2. Dynamics of the US defense spending, billion dollars (taking into account the fund of additional defense expenditures)

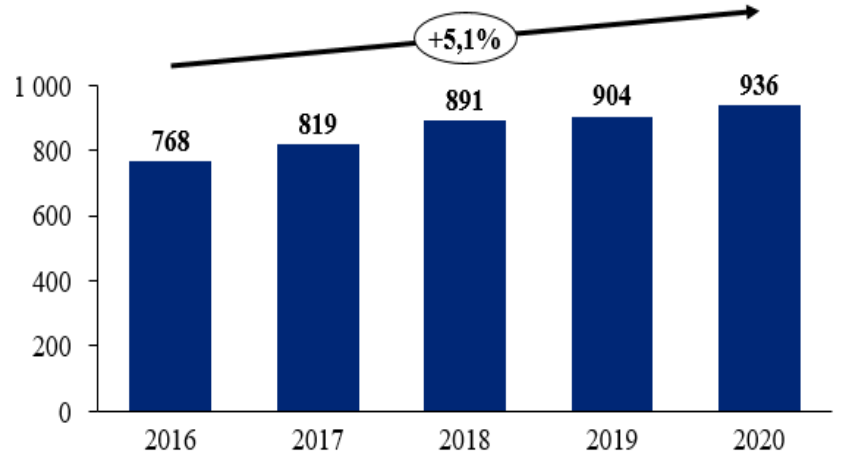

Source: compiled by the authors according to National defense budget estimates for FY 2020. 
the supply of lethal weapons to Kiev and strengthening the coast guard, will rise to $\$ 300$ million, along with $\$ 125$ million for strengthening the Baltic States protection. As part of strengthening the security of the Baltic States, among other things, joint military exercises and the supply of military equipment are planned. Special provision in the law provides additional funding of $\$ 250$ million to «counter the Kremlinss influence and Russiass ongoing disinformation operation.» It prohibits US military cooperation with Russia and Washington s recognition of the annexation of Crimea by the Russian Federation. The document expresses firmly support of the United States for the North Atlantic Alliance. It is also foreseen to update and expand strategies to combat the «malicious influence» of Russia and China (Egisman, 2020).

By cutting NATO funding, the United States is redistributing some of its funds to Ukraine and Georgia. Whereas previously they provided about $22 \%$ of direct NATO funding, covering the cost of maintaining headquarters, joint security investments, and individual military operations, the Trump administration is seeking to reduce its contribution to about $16 \%$, bringing it into line with contributions from Germany, which finances $14.8 \%$.

In China, the Old Doctrine of "Peopless War» has been replaced by a strategy of "active defense," which is the military doctrine of China in the new century. Supporting the global trend in the military sphere and relying on growing economic power, China is pursuing a course to improve the quality of defense capabilities based on advances in science and advanced technology.

In the open version of Chinass official military doctrine, the White Paper on Defense uses the phrase «new era» to describe the current stage of Chinass political and economic development, with key emphasis on an overall assessment of the global military-political situation, threats from other powerful powers, possible response of the country to challenges in the field of defense and national security. China expects to reach world leadership by 2050, for which particular attention is paid to technology, the promotion of Chinese economic interests and, consequently, their military and political support.

According to the new strategy, the country should have relatively compact, well-balanced types of armed forces, ready for both defensive and offensive actions according to the formula: "China is not going to attack anyone, but in case of aggression will retaliate.»

Chinass nuclear strategy, which has pledged not to be first to use nuclear weapons, corresponds with the concept of "nuclear deterrence»: China does not seek to achieve nuclear parity with developed countries, but its nuclear forces must be able to inflict irreparable damage on enemy in any military-political situation, which will force the latter to renounce the use of nuclear weapons. At the same time, it is worth noting that Chinass strategic nuclear forces are an offensive weapon in terms of their combat capabilities, and their role in the global balance of nuclear forces is significant.

Among the factors of instability, China considers, first of all, the widening gap between developed countries and developing countries; hegemony and policy from the standpoint of force pursued by individual states; intensification of rivalry for the natural resources of the planet.

As for the Asia-Pacific region (APR), the factors of its instability are the incompleteness of the peace process on the Korean Peninsula, as well as the Taiwan problem.

China is a permanent member of the UN Security Council, as well as the G20. In 2001, the leaders of China, Russia, Kazakhstan, Tajikistan, Kyrgyzstan and Uzbekistan founded the SCO (Shanghai Cooperation Organization) Alliance. The main tasks of the organization are to strengthen stability and security in the broad space uniting the member states, the fight against terrorism, extremism, drug trafficking, separatism, the development of economic cooperation, energy partnership, scientific and cultural cooperation.

China has long ranked second in the world in terms of

Fig. 3. Estimation of Chinass defense spending.

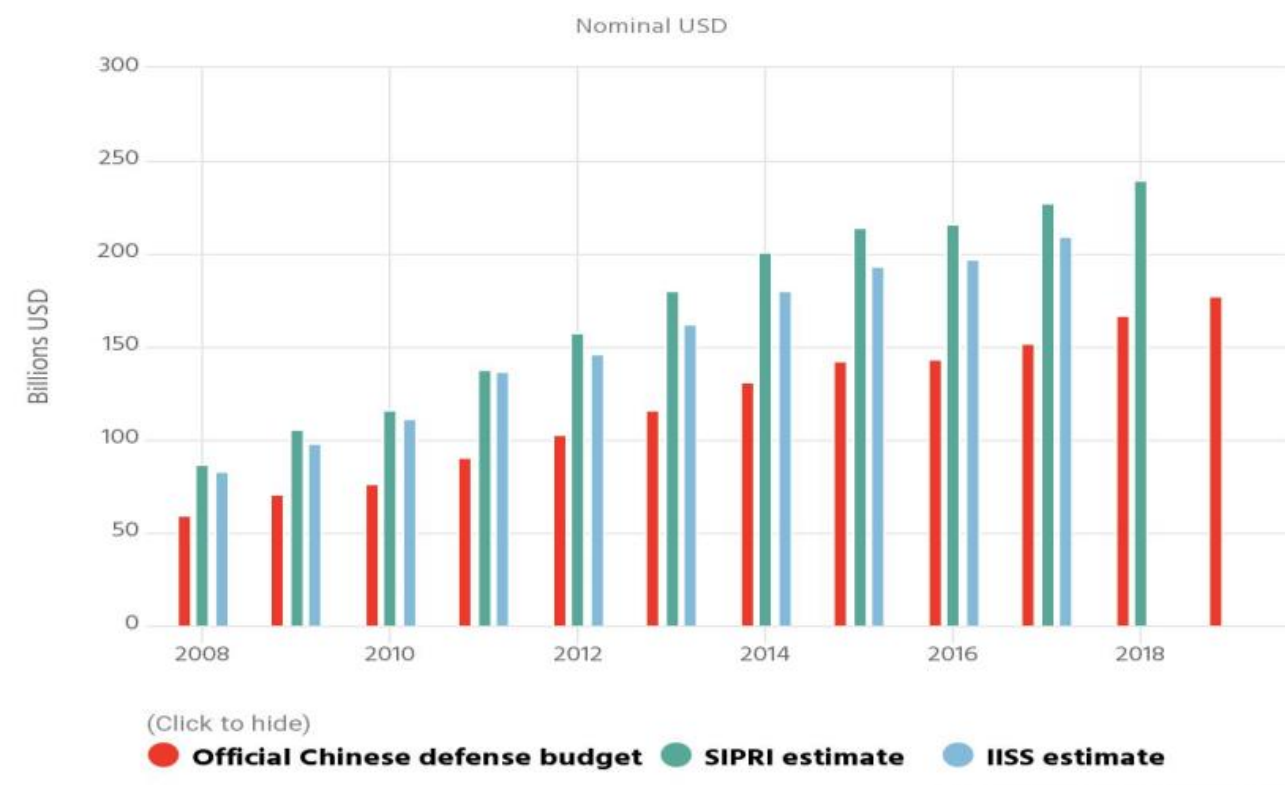


military spending after the United States and, apparently, is not going to stop there. Defense spending is growing $7-8 \%$ annually - faster than in other countries, although catching up with the leader of the war race the USA for China will not be easy. In addition, China is not making much effort to ensure military competition with the United States in different parts of the world. Its main approach is to oust Americans from the Asia-Pacific region, which they are systematically coping with.

In China, there is no generally accepted standard for reporting on military expenditures, although there are international mechanisms, in particular the United Nations Report on Military Expenditures, in which countries participate voluntarily with varying degrees of detail. China has been providing UN military expenditure materials since 2007, although their reports remain less transparent than in other countries. Therefore, the issue of actual military spending in China is debatable, as shown in Figure 3.

In general, the Reports on Defense Budgets point to their growth, with Beijing prioritizing military modernization as a top priority, even as economic growth slows. The lack of transparency in Chinass military spending leads to discrepancies between official figures and actual estimates. Official data do not take into account a number of expenditures related to the military sphere, including Chinass space programs, extra-budgetary revenues from military commercial enterprises, defense mobilization funds, permitted sale of land or food surpluses, recruitment allowances and others.

For the past 25 years, following the 1995-1996 crises in the Taiwan Strait, Chinass defense spending has been steadily rising in order to modernize it and increase its combat capability. The modernization of the Peopless Liberation Army is just one of many Chinese reforms that are being implemented to provide the country with world leadership in the cultural, economic, political and military spheres by the middle of the 21st century. Along with this, the modernization of national defense and armed forces is expected to be completed by 2035 .

Russia now ranks third in defense and investment spending, but its budget is ten times smaller than in the United States. At the same time, the budget financing of the national defense of the Russian Federation, as well as for China, is characterized by extremely high secrecy and the share of secret allocations is in order of magnitude higher than in developed countries. For example, in the closed part of the budget for 2019, more than $65 \%$ are expenditures on national defense, the army, the implementation of international obligations in the field of military-technical cooperation, applied research in the field of national defense. The costs for mobilization training of the economy and the nuclear weapons complex are $100 \%$ classified. In addition, the costs of some "peaceful» articles were partially covered. In general, the share of classified expenditures has been growing steadily since 2012 and peaked in $2016-21.7 \%$ of total annual expenditures. In 2017 and 2018, the figure decreased to 17.3 and $17.1 \%$, respectively. However, in the next few years, the secret part of the budget will expand: to $18.2 \%$ in 2020 and 20.6\% - in 2021 (Bulanov, Lomskaya, 2018).

Russiass military spending has doubled after the Kremlin leadership decided to aggression against Ukraine, which involved not only the annexation of Crimea, but the conquest of so-called Novorossia as well. In February-April 2014, Russian military expenditures amounted to 31 billion dollars or $6.7 \%$ of GDP ( $27.7 \%$ of total budget expenditures) [Unified..., 2014].

In the Concept of National Security of the Russian Federation, approved by the Decree of the President of the Russian Federation of January 10, 2000 № 243, the main tasks in the field of national security of the Russian Federation are to strengthen and maintain a high level of military capacity. Military security of the Russian Federation is recognized as the most important activity of the state (The Decree..., 2000). In the countrys budget, national defense expenditures have a second priority after national functions.

The military doctrine of the Russian Federation is a conceptual document of military planning. It is designed for a long-term period and allows for clarification if the situation changes. The edition of the Military Doctrine of the Russian Federation in 2014 identifies among the main external military dangers new threats to Russia in connection with the situation in and around Ukraine and the events in North Africa, Syria, Iraq and Afghanistan. In addition, the external threats of the Russian Federation included:

- building NATO is force capabilities and bringing NATO is military infrastructure closer to Russiass borders;

- deployment of US strategic missile defense systems;

- violation of international agreements by some states, as well as non-compliance with previously concluded international treaties in the field of arms prohibition, restriction and reduction.

The internal threats include "activities on information influence on the population, primarily on young citizens of the country, aimed at undermining the historical, spiritual and patriotic traditions in the field of defense of the Fatherland» (Military..., 2014). Russia is a member of a number of military alliances and international organizations: The Collective Security Treaty Organization (CSTO); Commonwealth of Independent States (CIS), Organization for Security and Cooperation in Europe (OSCE), Shanghai Cooperation Organization (SCO); Union of States of Russia and Belarus (SGRB); United Nations (UN). Due to the Military Doctrine of 2014, one of the tasks of the Russian Federation to deter and prevent military conflicts, envisages strengthening cooperation in the field of international security within the framework of military alliances to which Russia is a member.

World economic leadership in modern conditions is impossible without appropriate defense and military power. Therefore, NATOss leadership is pursuing an active policy of increasing defense spending, taking into account security threats. At the same time, the US contribution to the defense of NATO countries remains significant. In the future, it is possible to expand the NATO network, including at the expense of Ukraine and Georgia, which will increase the overall financial costs of this organization. 
Emphasizing the leading role of the United States in the North Atlantic Alliance, it should be acknowledged that in a time of rising human values, the US defense spending (\$ 936 billion) is not, in our view, appropriate. It is worth taking into account the huge difference in defense financing with the countries closest in this indicator, including their strategic competitors (China - 250 billion dollars, the Russian Federation - 60 billion dollars).

The increase in world defense spending is complemented by the long-standing trend of a number of Asian countries to increase funding for military needs. In 2019, the growth of global defense spending was the largest since 2010.

Russia, which has embarked on a large-scale rearmament program since the collapse of the Soviet Union, maintains a trend of aggressive growth in classified military spending that poses a threat to peace and international stability. Proof of this are the Transdniestrian conflict, the wars in South Ossetia and Abkhazia, the Russian-Georgian war, the civil war in Syria, the annexation of Crimea by Russia, and the hybrid war waged by Russia against Ukraine.

\section{REFERENCES}

Military expenditures of the world [Reference data] (2002), Foreign military review, № 6, 15-20.

Cheberyako, O., \& Varnalii, Z. (2017) «Financial prerequisites and assessment of defense under the conditions of RussianUkrainian hybrid war», Scientific newsletter of Polissya. Chernihiv, №4, 143 - 149.

Cheberyako, O. (2017) «Financial support of Ukrainess defense as a basis of national security in the conditions of armed aggression of the Russian Federation", Scientific Letters of Academic Society of Michal Baludansky, №5, part 2, 49-58.

Rating of the strongest armies in the world 2020. Available at: https://www.ukrmilitary.com/2020/05/top-army-2020.html

The United States Code: Section 7062. Available at: https: //www.law.cornell.edu/uscode/text/10/7062

The North Atlantic Treaty Organization. Available at: https: //www.nato.int/

Stockholm International Peace Research Institute. Available at: https://www.sipri.org/

National defense budget estimates for FY 2020. Available at: https://comptroller.defense.gov/Portals/45/Documents/ defbudget/fy2020/FY20_Green_Book.pdf

US Military Budget, Its Components, Challenges, and Growth. Available at: https://www.thebalance.com/u-s-military-budgetcomponents-challenges-growth-3306320

Egisman, V. (2020) «The US defense budget for 2020: what does Washington plan for Russia?». Available at: https://www. golos-ameriki.ru/a/us-defence-budget-2020-russia/5217239.html

The Decree of the President of the Russian Federation of April 21, 2000 № 706 «On Approval of the Military Doctrine of the Russian Federation». Available at: http://kremlin.ru/acts/bank/15386

Military doctrine of the Russian Federation in the edition of 2014. Available at: https: //rg.ru/2014/12/30/doktrina-dok.html Unified portal of the budget system of the Russian Federation. Available at: http: //budget.gov.ru/

Bulanov, K., \& Lomskaya, T. (2018) «Experts called illegal the high share of secret budget expenditures». Available at: https:// https://www.vedomosti.ru/economics/articles/2018/10/17/783943-dolyu 